\title{
BEE-KILLING ASILIDS IN NEW ENGLAND
}

\author{
By Stanley W. Bromley \\ Bartlett Tree Research Laboratories, \\ Stamford, Connecticut
}

While Robber flies have been reported as destructive to honey-bees in Nebraska, Missouri, Texas, Florida and other Southern States, no species has been noted as of economic importance in this respect in New England.

In my observations on the prey of Robber flies in southcentral Massachusetts as reported in Psyche, December 1914, p. 192, I mentioned that I had not observed Asilids feeding to any extent on honey-bees, although I listed certain species such as Proctacanthus philadelphicus Macq. and Diogmites (Deromyia) umbrinus Loew as partial to worker vespids.

A few years later, however, a situation came to my attention where Asilids were attacking bees extensively. This observation is here published for the first time. The species concerned was Promachus fitchii O. S. the famous old "Nebraska beekiller" whose habits were first described by Fitch in his New York report of 1864.

About a mile and a half south of Southbridge, Massachusetts, lies a large drumlin called Lebanon Hill. Part way up the hill was an apiary of 15 or 20 hives. Adjacent to the bee yard were several dry hayfields which, although mowed yearly, were reaching a condition described as "run-out" by the farmers, because the better grasses were beginning to give way to such plants as ox-eye daisy, sorrel and black-eyed susan; a condition very probably due to white grub infestations. The dominants were, however, still timothy, red-top and some scattered clover.

These hayfields were fairly seething with Promachus fitchii and I soon saw that the majority of prey taken by them consisted of worker honey-bees. On July 10-13 (1915) and July 15 (1916) I collected 42 of these flies, both males and females, each with a honey-bee as prey. This represented in all about three hours collecting. 
A summary of the records I have collected of honey-bees falling victims to Asilids in New England between 1911 and 1941 follows. These observations were made largely at Southbridge, Massachusetts; Wallingford and Stamford, Connecticut; and nearby areas.

\begin{tabular}{|c|c|}
\hline Asilid species & $\begin{array}{c}\text { Number of } \\
\text { instances of } \\
\text { honey-bee prey }\end{array}$ \\
\hline Promachus fitchii O. S. & $\ldots 56$ \\
\hline Diogmites umbrinus Loew & 40 \\
\hline Proctacanthus philadelphicus Macq. & 22 \\
\hline Proctacanthus rufus Williston ...... & 14 \\
\hline Promachus bastardii Macq. . . & 11 \\
\hline Diogmites discolor Loew .. & 7 \\
\hline Bombomima thoracica Fabr. & 2 \\
\hline Bombomima grossa Fabr. . . & 1 \\
\hline Bombomima flavicollis Say & 1 \\
\hline Proctacanthus brevipennis Wied. & 1 \\
\hline Erax aestuans L. . & 1 \\
\hline
\end{tabular}

Of these 11 species, Diogmites discolor is restricted to the extreme southwest corner of Connecticut, Proctacanthus rufus to certain sand plains or washouts along some of the larger streams and rivers, Bombomima grossa is decidedly uncommon, and Proctacanthus brevipennis is found almost exclusively in level sandy open woods. The remainder are widespread and locally abundant. Erax aestuans is probably the most abundant and generally distributed of Southern New England Robber flies.

C. W. Johnson's list of N. E. Diptera (1925) recorded 86 species of Asilidæ in New England. Of this number it may be seen that only 11 species ordinarily kill honey-bees and of these only 3 or 4 at most may kill bees in any quantities. Even with the leading species on the list, Promachus fitchii, it would be very rarely that the effect of bee-killing by this insect on a commercial apiary would be felt.

In fact, it would seem quite probable that any possible loss which $P$. fitchii might occasion to bee-keepers would be more than counterbalanced by the control of Phyllophaga grubs exerted by the larvæ of this fly. Such benefits, however, would be much less apparent now than thirty years ago due to the 
decline in the utilization of grass for hay and the abandonment of mowing in many parts of New England as a result of the displacement of the horse by motor driven vehicles.

Promachus fitchii tends to disappear from hayfields after they have been abandoned and an old-field succession of varying stages from grasses to shrubs and trees takes place. So after all, the species begins to lose any significance it might have had as a bee-killer thirty years ago, with the changing times and conditions of more recent years. 

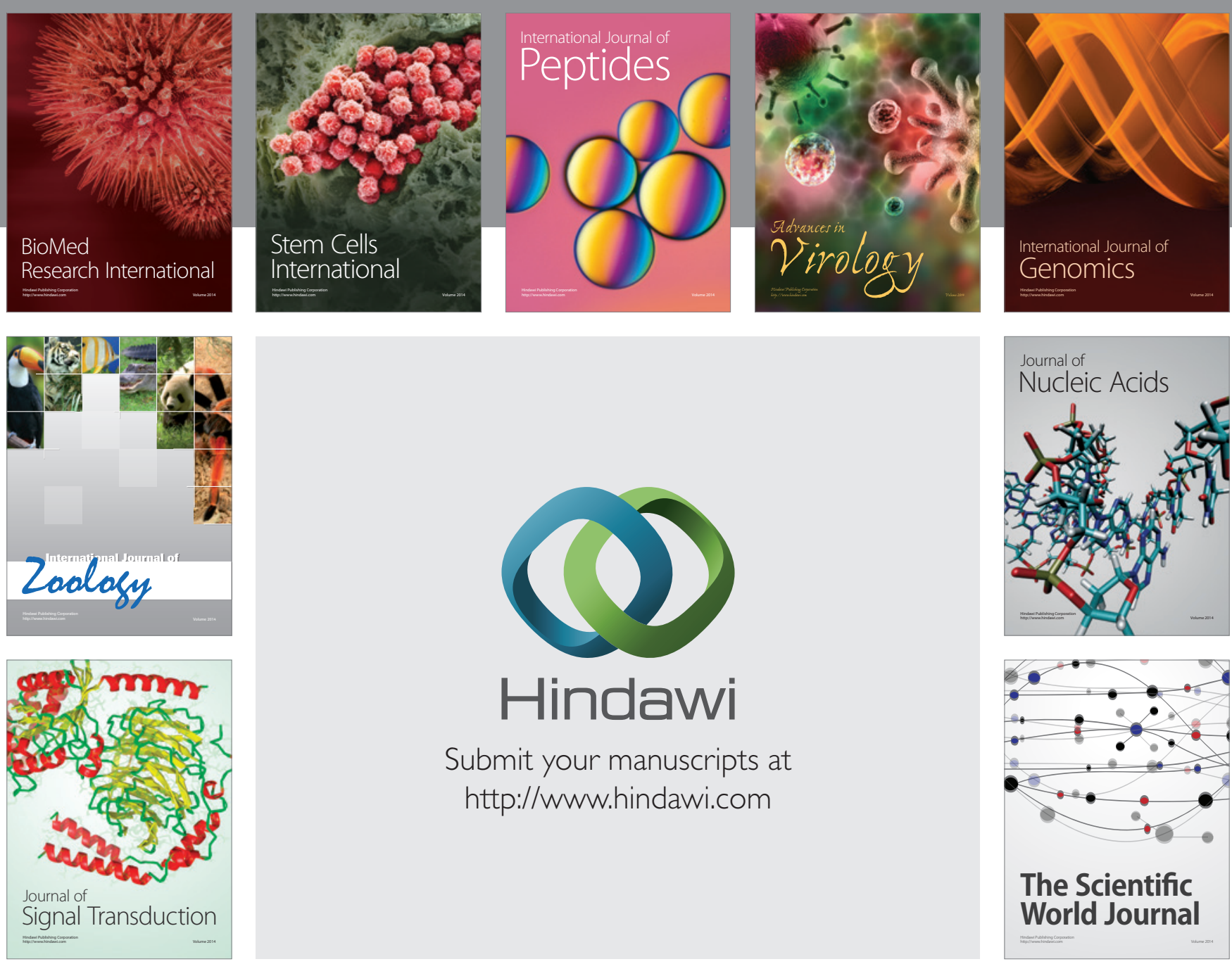

Submit your manuscripts at

http://www.hindawi.com
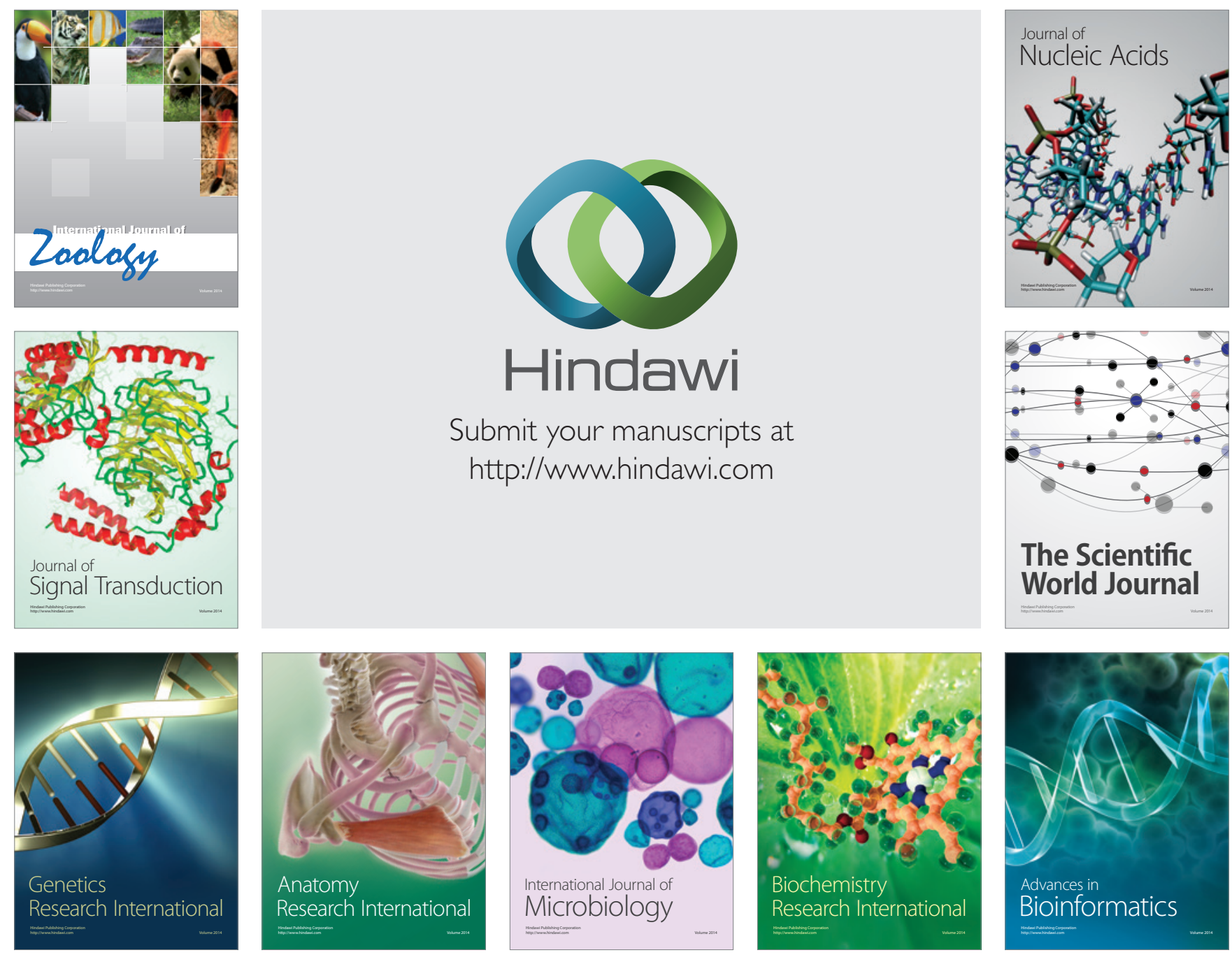

The Scientific World Journal
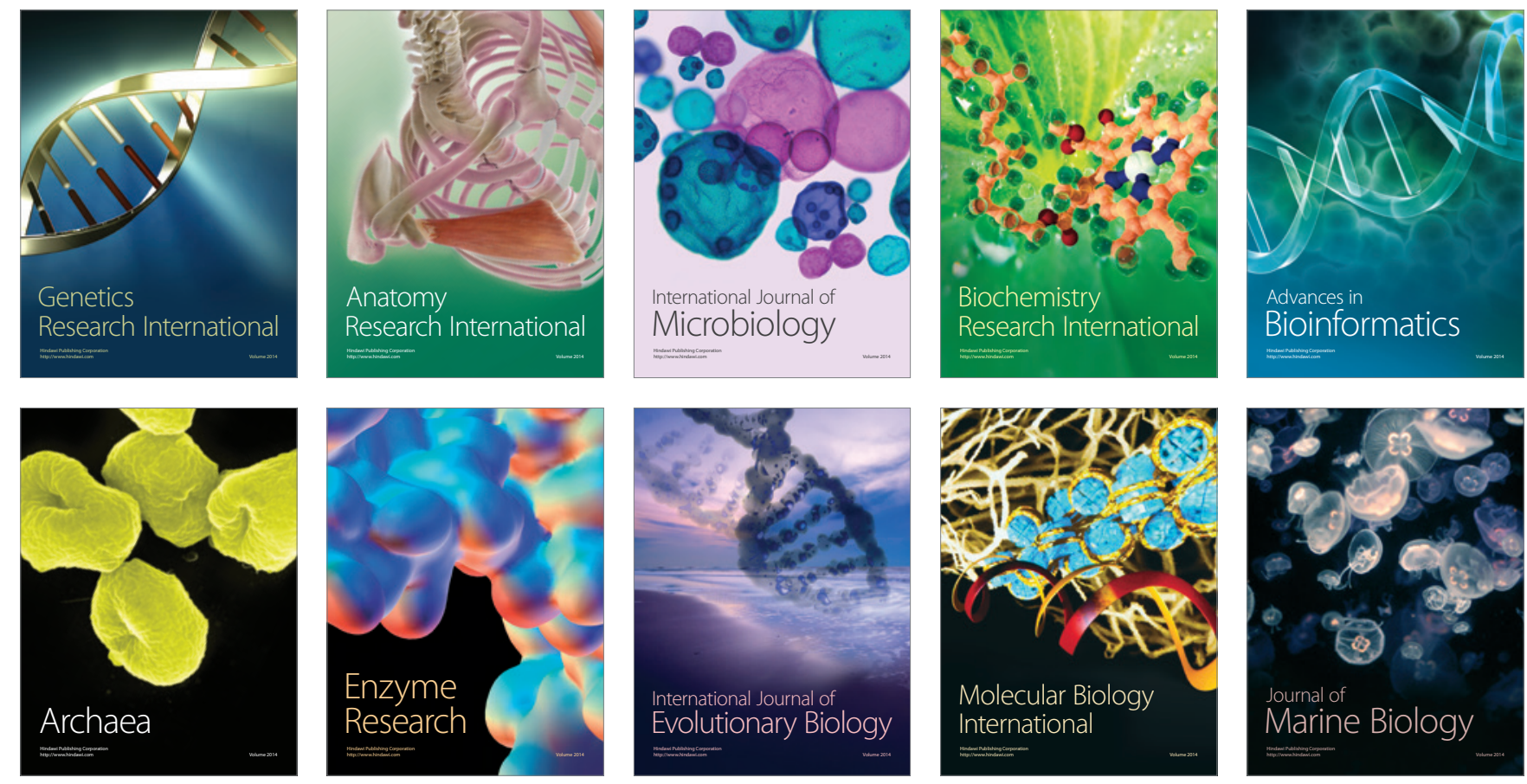